\title{
Optimalisasi Penerapan Metoda Latihan untuk Meningkatkan Hasil Belajar Bahasa Indonesia Materi Pokok Menganalisis Teks Prosedur
}

\section{Syarifah* $^{*}$}

SMK Negeri 41 Jakarta

\begin{tabular}{l} 
A R T I C L E I N F O \\
\hline Article history: \\
Received 20 May 2019 \\
Received in revised form \\
10 June 2019 \\
Accepted 30 July 2019 \\
Available online 28 \\
August 2019 \\
\hline
\end{tabular}

Kata Kunci:

metoda latihan, hasil

belajar, menganalisis teks prosedur

Keywords: training methods, learning outcomes, analyzing procedure texts.

\begin{abstract}
A B S T R A K
Penelitian ini bertujuan untuk mendeskripsikan: peningkatan kemampuan menganalisis teks prosedur melalui penerapan metoda latiha pada siswa kelas XI, MM Semester Ganjil SMK Negeri 41 Jakarta Tahun Pelajaran 2016/2017. Penelitian ini dilaksanakan melalui dua siklus dimana rancangan tersebut dikelompokkan atas empat prosedur pengembangan, yang meliputi: (1) perencanaan, (2) tindakan, (3) observasi dan (4) refleksi. Subjek penelitian adalah siswa kelas XI MM pada semester Ganjil yang berjumlah 31 orang siswa. Pengumpulan data menggunakan pedoman lembar penilaian, tes hasil belajar, catatan lapangan, dan dokumentasi kegiatan. Teknik analisis data dalam penelitian ini mencakup proses tindakan kelas yang dilakukan secara diskriftif dan hasil analisis tindakan yang berupa skor secara kuantitatif. Indikator keberhasilan penelitian ini adalah selama proses pembelajaran dan dilakukannya refleksi ternyata adanya peningkatan hasil belajar siswa, terhadap mata pelajaran Bahasa Indonesia dengan materi pokok menganalisis teks prosedur melalui penerapan metode belajar latihan dan hasilnya adalah: pada siklus I nilai rata-rata 76,3 dengan ketuntasan belajar sebesar $83,9 \%$, sedangkan pada siklus II nilai rata-rata meningkat menjadi 85,3 dengan ketuntasan belajar sebesar $100 \%$. Simpulan dalam penelitian ini: penerapan metode pembelajaran latihan
\end{abstract} terhadap mata pelajaran Bahasa Indonesia dengan materi menganalisis teks prosedur terbukti dapat meningkatkan hasil belajar kelas XI.MM Semester ganjil SMK Negeri 41 Jakarta secara signifikan.

A B S T R A C T

This study aims to describe: an increase in the ability to analyze procedural texts through the application of training methods to students of class XI, MM Odd Semester of SMK Negeri 41 Jakarta Academic Year 2016/2017. This research was carried out through two cycles where the design was grouped into four development procedures, which included: (1) planning, (2) action, (3) observation and (4) reflection. The research subjects were students of class XI MM in the Odd semester totaling 31 students. Data collection uses guidelines for assessment sheets, learning outcomes tests, field notes, and documentation of activities. The data analysis technique in this study includes the class action process carried out discretely and the results of action analysis in the form of quantitative scores. The indicator of the success of this research is that during the learning process and reflection it is evident that there is an increase in student learning outcomes on Indonesian subjects with the subject matter analyzing the procedure text through the application of training learning methods and the results: in the first cycle the average score is 76.3 with completeness learning is $83.9 \%$, while in cycle II the average value increases to 85.3 with learning completeness of $100 \%$. Conclusions in this study: the application of training learning methods to Indonesian language subjects with material analyzing text procedures proved to be able to significantly improve the learning outcomes of class XI. MM Semester of SMK Negeri 41 Jakarta. 


\section{Pendahuluan}

Dalam kehidupan, pendidikan mempunyai peranan yang sangat penting. Pendidikan digunakan untuk mengembangkan kemampuan yang dimiliki manusia dan meningkatkan mutu kehidupan suatu bangsa. Pendidikan menjadi faktor utama penentu kemajuan bangsa. Pendidikan merupakan salah satu upaya dalam meningkatkan kualitas sumber daya manusia. Peningkatan kualitas sumber daya manusia merupakan sasaran pembangunan saat ini (Puspita, 2016). Pendidikan merupakan salah satu faktor yang memerlukan perhatian tersendiri dalam pembangunan nasional yaitu usaha untuk mencerdaskan kehidupan bangsa, karena dengan pendidikan akan dapat meningkatkan kualitas sumber daya manusia (SDM) yang dijadikan modal utama pelaksanaan pembangunan. Pada kenyataannya kualitas SDM di Indonesia masih rendah, khususnya dibidang pendidikan. Upaya untuk meningkatkan kualitas belajar mengajar yang berpuncak pada mutu pendidikan terdapat beberapa unsur yang saling berkaitan yang meliputi peserta didik, pendidik, tujuan, isi pendidikan, dan cara/metode. Proses belajar pembelajaran dikatakan efektif apabila seluruh peserta didik terlibat secara aktif baik mental, fisik maupun sosial. Oleh karena itu, guru dikatakan sebagai penggerak perjalanan belajar dan fasilitator belajar peserta didik yang diharapkan mampu membantu memecahkan tingkat kesukaran yang dialami peserta didik (Efendi, 2014). Bahasa memiliki peran yang penting dalam perkembangan intelektual, sosial, dan emosional peserta didik dan merupakan penunjang keberhasilan dalam mempelajari semua bidang studi. Pembelajaran bahasa diharapkan membantu peserta didik mengenal dirinya, budayanya, dan budaya orang lain, mengemukakan gagasan dan perasaan, berpartisipasi dalam masyarakat yang menggunakan bahasa tersebut dan menemukan serta menggunakan kemampuan analitis dan imajinatif yang ada pada dirinya. Pembelajaran bahasa Indonesia diarahkan untuk meningkatkan kemampuan peserta didik untuk berkomunikasi dalam bahasa Indonesia dengan baik dan benar, baik secara lisan maupun tulisan, serta menumbuhkan apresiasi terhadap hasil karya kesastraan manusia Indonesia (Idin, 2014). Menurut Nurlawati (2016) tujuan pembelajaran bahasa Indonesia untuk memperbaiki proses komunikasi baik itu secara lisan maupun tulisan. Selain itu, pendapat di atas juga mencerminkan bahwa proses pembelajaran bahasa Indonesia benar-benar harus menuntun siswa agar dapat berkomunikasi dengan baik. Kemampuan siswa dalam menganalisis teks prosedur pada mata pelajaran Bahasa Indonesia adalah salah satu kemampuan yang harus dikuasai oleh siswa dan kemampuan tersebut sangat dibutuhkan untuk memupuk keterampilan siswa dalam membaca, menulis, menyimak dan berbicara dalam bahasa Indonesia. Dari keempat aspek tersebut saling terkait dan tidak dapat dipisahkan. Jikan dalam pembelajaran menganalisis tek prosedur siswa terlebih dahulu harus membaca tek yang akan dianalisisnya, kemudian hasil analisis tersebut ditulis dalam bentuk catatan - catatan, kemudian didiskusikan dalam bentuk dialoh atau berbicara, berkomunikasi dan dari komunikasi terserbut ada masukan-masukan yang harus didengarkan untuk dijadikan input dalam melakukan analisis teks prosedur.

Pada era globalisasi sekarang ini telah menjadi kemajuan yang sangat meningkat terutama di bidang teknologi informasi dan komunikasi. Kemajuan tersebut menuntut dukungan keterampilan dalam berbahasa Indonesia yang baik dan benar, dimana dari keempat aspek tersebut diatas berguna sekali dalam melakukan komunikasi. Berdasarkan pengamatan yang dilakukan Peneliti pada tahap awal dari penelitian ini bahwa kemampuan menganalisis teks prosedur bagi siswa kelas XI MM SMK Negeri 41 Jakarta berdasarkan hasil tes Prasiklus yang dicapai oleh siswa belum mencapai nilai yang distandarkan sekolah yaitu 79 untuk mata pelajaran Bahasa Indonesia. Sedangkan hasil tes prasiklus yang dicapai siswa dengan nilai rata-rata 69,4 dan ketuntasan belajar mencapai 51,6\%.. Berdasarkan kondisi demikian Peneliti berupaya untuk melakukan perbaikan - perbaikan melalui Penelitian Tindakan Kelas dengan menerapkan metoda latihan. Sehubungan dengan hal tersebut diatas maka judul yang diangkat dalam penelitian ini adalah: Optimalisasi Penerapan Metoda Latihan untuk Meningkatkan Hasil Belajar Bahasa Indonesia Materi Pokok Menganalisis Teks Prosedur Bagi Siswa Kelas XI MM Semester Ganjil SMK Negeri 41 Jakarta Tahun Pelajaran 2016/2017.

Metoda latihan sering digunakan oleh guru dalam rangka meningkatkan kemampuan siswa (skills) agar siswa dapat secara kompeten melakukan aktivitas pembelajaran berdasarkan materi yang dipelajarinya. Metoda adalah cara yang digunakan untuk menyampaikan materi pelajaran dalam upaya mencapai tujuan. Dewasa ini aktivitas guru yang bertindak sebagai fasilitator dan pembimbing bagi siswa berupaya semaksimal mungkin mengembangkan metoda pembelajaran agar tepat dengan materi yang diajarkannya. Pengembangan kurikulum dan pembelajaran (2002: 22) juga sesuai dengan petunjuk pelaksanaan kegiatan belajar mengajar kelas harus mencantumkan metoda belajar yang sesuai dengan materi dalam kurikulum tersebut. Metoda latihan dapat disajikan pada bagian ini yaitu suatu latihan yang diberikan guru kepada siswanya agar siswa siap untuk melaksanakannya. Menurut Wahyuni (2013) drill adalah latihan dengan praktek yang dilakukan berulang kali atau kontinu untuk mendapatkan 
keterampilan dan ketangkasan praktis tentang pengetahuan yang dipelajari. Lebih dari itu diharapkan agar pengetahuan atau keterampilan yang telah dipelajari itu menjadi permanen, mantap, dan dapat dipergunakan setiap saat oleh yang bersangkutan. Menurut Rahmadani (2015) metode latihan (drill) merupakan suatu cara mengajar dengan memberikan latihan-latihan terhadap apa yang telah dipelajari siswa, sehingga memperoleh suatu keterampilan tertentu. Metode ini merupakan metode pembelajaran yang tepat untuk meningkatkan kemampuan Belajar siswa. Metoda latihan ini sangat sesuai untuk melatih keterampilan, baik keterampilan fisik maupun mental dan menurut pendapat Sagala (2007: 202) adalah: metode latihan (Driil) merupakan suatu cara mengajar yang baik untuk menanamkan kebiasaankebiasaan tertentu. Latihan adalah suatu teknik mengajar yang mendorong siswa untuk melaksanakan kegiatan latihan agar memiliki ketangkasan/keterampilan yang lebih tinggi dari apa yang dipelajari.

\section{Metode}

Penelitian ini adalah Penelitian Tindakan kelas, maka metode yang digunakan adalah metoda deskriptif analisis hasil Penelitian Tindakan Kelas (PTK), yaitu studi yang digunakan untuk mengumpulkan data, mendeskripsikan, mengolah, menganalisa, menafsirkan dan menyimpulkan data sehingga diperoleh gambaran yang sistematis.

Penelitian Ini dilakukan di SMK Negeri 41 jakarta Tahun Pelajaran 2016/2017 dengan Subjek Penelitian sebanyak 31 orang siswa kelas XI.MM Semester Ganjil. Kelas itu dijadikan sebagai subjek penelitian karena rata-rata hasil tes awal (Pra siklus), adalah 69,4 dan ketuntasan belajar mencapai $51,6 \%$, sehingga berdasarkan kondisi demikian peneliti terdorong untuk melakukan perbaikan melalui penelitian ini, agar hasil belajar siswa dapat ditingkatkan.

Rancangan penelitian tindakan kelas di pusatkan pada situasi dalam proses belajar di kelas dan berlangsung secara kolaborasi/kerjasama yang positif, saling bertukar pikiran untuk menyelesaikan masalah, dalam pelaksanaan proses pembelajaran di kelas. Rancangan penelitian ini dilakukan atas dasar empiris yang didukung program penelitian tindakan kelas. Untuk mendapat gambaran yang lebih jelas tentang rancangan penelitian dapat dilihat bagan di bawah ini:

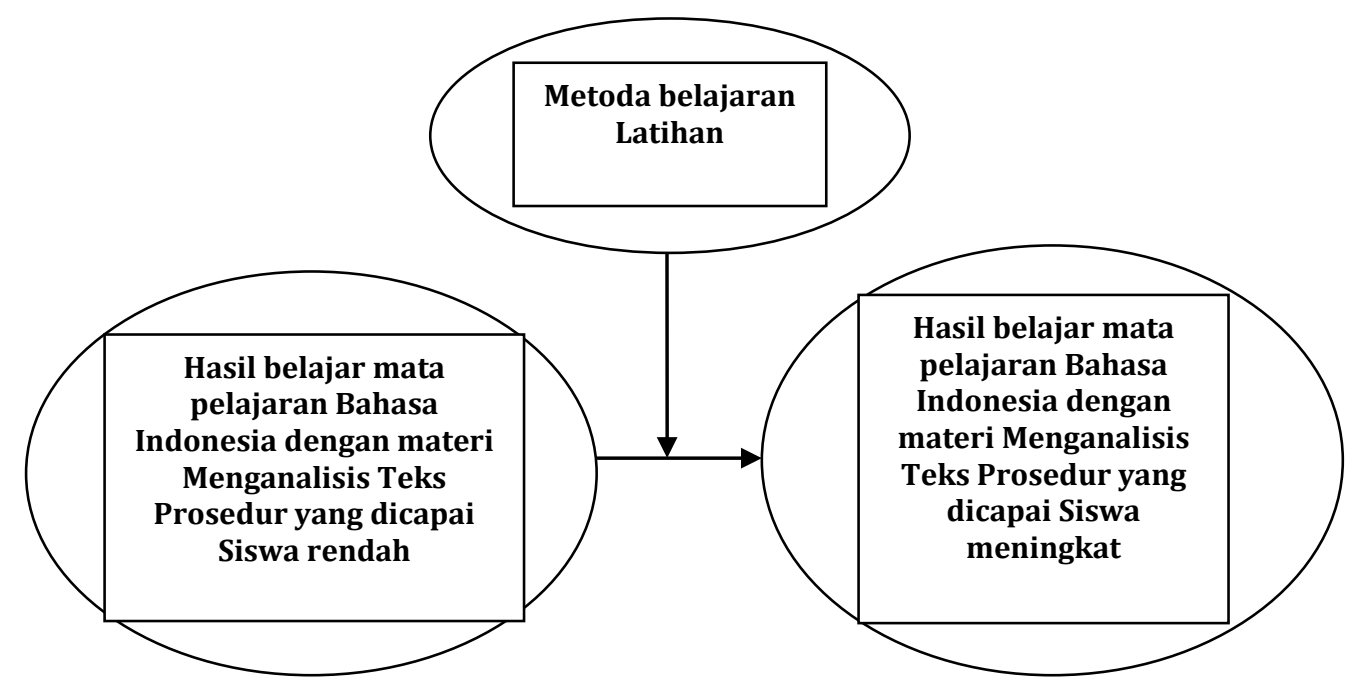

Gambar 1. Rancangan Penelitian

Rancangan Penelitian disusun dan bermanfaat sebagai:

1. Kerangka operasional penelitian (blue print).

2. Penegasan makna dan kedalaman (intensitas) serta keleluasaan (ekstensitas) penelitian.

3. Perkiraan pelaksanaan penelitian yang akn dihadapi dan rancangan alteratif penyelesaiaanya.

4. Kontrol untuk mengetahui kelemahan hasil penelitian.

Pengumpulan data dalam Penelitian Tindakan Kelas ini dilakukan dengan menggunakan Instrumen Penelitian yang terdiri dari: tes uji kompetensi, angket siswa, lembar observasi, wawancara, dan refleksi. Hasil yang didapat melalui Penelitian Tindakan Kelas ini terutama pada tahap observasi dilakukan analisis oleh peneliti agar mendapat gambaran data dan informasi yang diperlukan untuk 
penulisan hasil penelitian ini lebih lanjut. Dengan berpatokan pada hasil analisis tersebut, maka dapat direncanakan tindak lanjut pada siklus berikutnya.

Analisis data menggunakan teknik kualitatif berupa hipotesis dan rumusan perhitungan data berupa nilai siswa, sedangkan deskripsi terhadap data yang diperoleh diuraikan secara deskriptif. Setelah data terkumpul dan diperiksa, bila memenuhi persyaratan, maka data tersebut diolah dan dihitung presentasenya. Sedangkan langkah-langkahnya adalah: mengumpulkan data, menyeleksi data, mengklasifikasi data, dan menghitung prosentase.

Indikator kinerja dibutuhkan dalam penelitian ini adalah agar pelaksanaan penelitian dapat berjalan sesuai rencana dan jadwal serta mendapatkan hasil yang positif dan sesuai dengan apa yang dikehendaki yaitu peningkatan hasil belajar siswa diharapkan dalam penelitian ini terjadi peningkatan yang baik diperoleh dari setiap siklus. Dengan hasil yang baik diperoleh dalam penelitian ini maka akan berdampak pada peningkatan kemampuan siswa dalam memahami konsep-konsep materi pelajaran Bahasa Indonesia secara lebih baik.

\section{Hasil Dan Pembahasan}

\section{Siklus I}

Penelitian Tindakan Kelas yang dilkaksanakan di kelas XI.MM pada semester ganjil SMK Negeri 41 Jakarta telah menghasilkan sejumlah data dan informasi tentng keberhasilan siswa yang menjadi subjek dalam Penelitian ini. Hasil yang di capai antar siklus terhadap mata pelajaran Bahasa Indonesia, dengan materi menganalisis teks prosedur pada siklus I melalui penerapan metoda belajar latihan telah menunjukkan peningkatan dari prasiklus. Hal ini dibuktikan bahwa sebanyak 26 orang siswa pada siklus I memperoleh nilai diatas KKM dengan katagori tuntas, sedangkan sebanyak 5 orang siswa yang mendapat nilai dibawah KKM dengan katagori belum tuntas. Adapun nilai rata-rata kelas memperoleh angka 76,3 dengan ketuntasan belajar mencapai 83,9\%. Namun demikian masih perlu dilakukan perbaikan perbaikan pada siklus II melalui tindakan /refleksi, karena masih ada 5 orang siswa yang belum mencapai ketuntasan belajar pada siklus I.

Bagi siswa yang belum mencapai ketuntasan pada siklus I akan dilakukan perbaikan dalam bentuk tindakan refleksi pada siklus II. Jika dibandingkan hasil yang dicapai pada prasiklus dengan siklus I dapat disajikan dalam gambar grafik berikut ini:

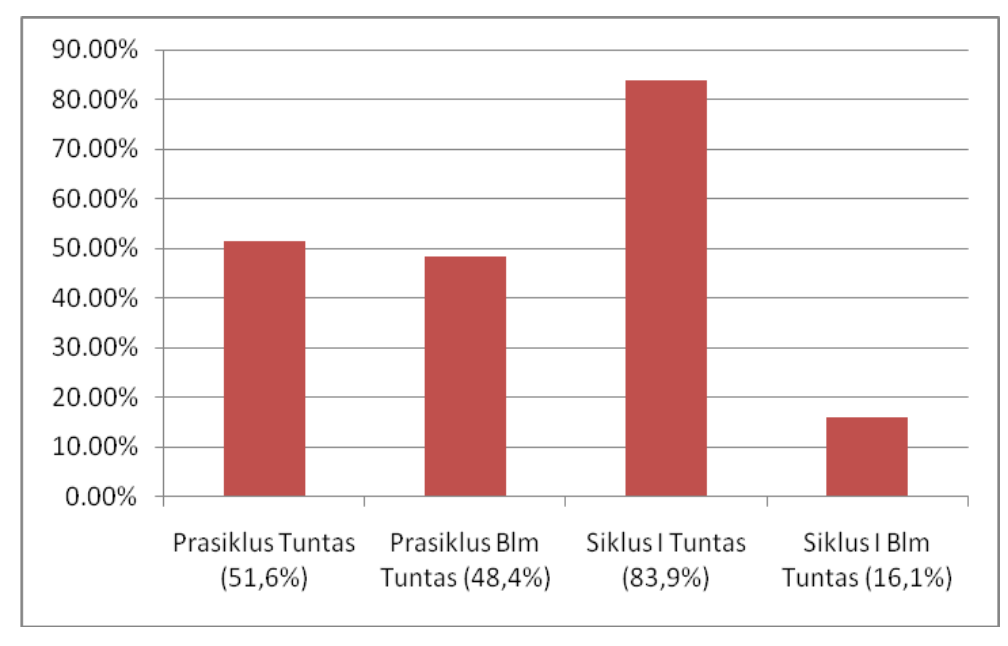

Gambar 2. Grafik Siklus I

Keterangan :

1. Ketuntasan Belajar yang dicapai pada sprasiklus $=51,6 \%$

2. Siswa yang belum tuntas di Prasiklus $\quad=48,4 \%$

3. Ketuntasan Belajar yang dicapai pada siklus I $\quad=83,9 \%$

4. Siswa yang belum tuntas pada siklus I $\quad=16,1 \%$ 


\section{Siklus II}

Pelaksanaan pembelajaran Bahasa Indonesia dengan menggunakan metoda belajar latihan terbukti pada siklus II sebanyak 31 siswa mampu meningkatkan hasil belajar dengan maksimal.

Peningkatan hasil belajar siswa memperoleh nilai yang lebih baik pada siklus II. Adapun hasil nilai yang diperoleh siswa pada siklus II adalah sebanyak 31 orang siswa (100\%) siswa yang telah memperoleh nilai diatas KKM dengan kata gori tuntas, sebanyak 31 orang siswa $(100 \%)$ dan siswa yang telah meningkat hasil belajarnya pada siklus II ini telah menunjukkan kemampuan yang sangat baik dalam menganalisis teks prosedur. Jumlah nilai rata-rata pada siklus II ini adalah 85,3 dengan keberhasilan $100 \%$. Dengan dilakukan refleksi secara maksimal maka pada siklus II telah terjadi peningkatan hasil belajar Bahasa Indonesia bagi siswa kelas XI.MM SMK Negeri 41 Jakarta pada Semester Ganjil tahun pelajaran 2016/2017 sesuai dengan harapan peneliti.

Setelah dilaksankannya evaluasi terhadap Pelaksanaan Penelitian Tindakan Kelas yang dilaksanakan di kelas XI.MM pada Semester Ganjil di SMK Negeri 41 Jakarta pada tahun pelajaran 2016/2017, maka Penelitian Tindakan Kelas ini dinyatakan berhasil dengan baik.

Keunggulan dari metoda latihan dalam pembelajaran Bahasa Indonesia mampu meningkatkan semangat dan motivasi belajar siswa. Hasil tersebut dapat ditampilkan secara keseluruhan dalam bentuk grafik sebagai berikut:

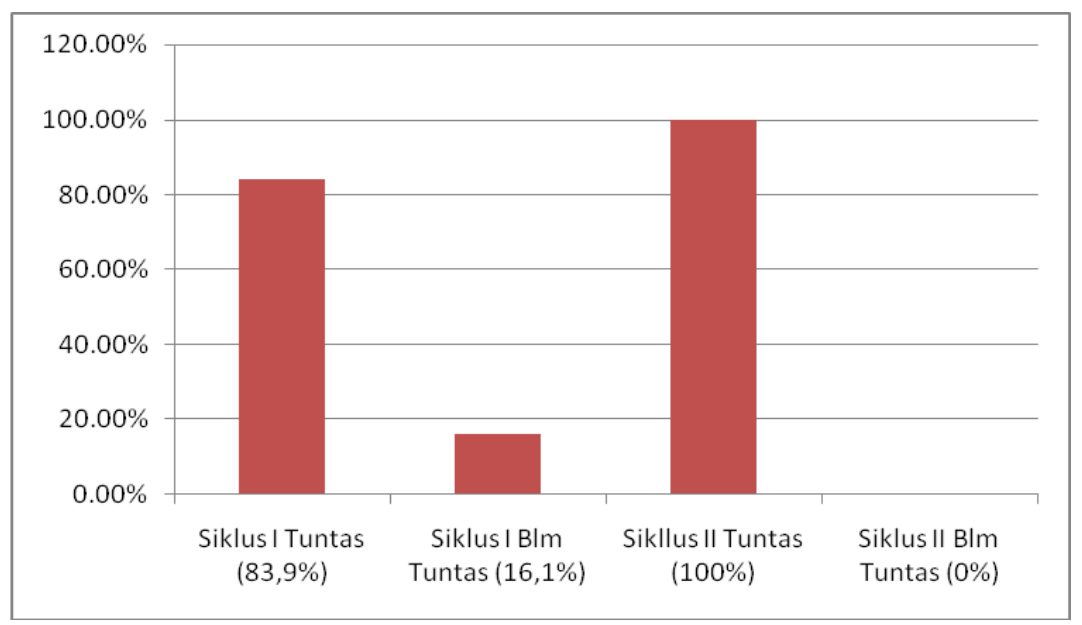

Gambar 3. Grafik Siklus II
Keterangan :
1. Keberhasilan yang dicapai di siklus $1=83,9 \%$
2. Siswa yang Belum Tuntas di Siklus I $\quad=16,1 \%$
3. Keberhasilan yang dicapai di Siklus II $\quad=100 \%$
4. Siswa yang Belum Tuntas di Siklus II $\quad=0 \%$

Dari data nilai hasil evaluasi siswa kelas XI.MM. yang menjadi subjek dalam penelitian ini, pada siklus II yang telah menunjukkan hasil yang baik dan memuaskan. Dengan demikian adanya pengaruh yang positif terhadap penerapan metoda belajar latihan pada mata pelajaran Bahasa Indonesia di SMK Negeri 41 Jakarta.

Keseluruhan hasil yang telah dicapai dalam penelitian tindakan kelas ini dapat disajikan dalam tabel dibawah ini: 
Tabel 1. Rekapitulasi Hasil Penelitian Tindakan Kelas pada pretest/prasiklus

\begin{tabular}{clcccr}
\hline \multirow{2}{*}{ No. } & \multicolumn{1}{|}{ Kreteria } & \multicolumn{3}{c}{ Jenis Tindakan } & \multirow{2}{*}{ Ket. } \\
\cline { 3 - 5 } & & Pre test/Prasiklus & S.I & S.II & \\
\hline 1. & Jumlah Nilai & 2152 & 2364 & 2644 & Meningkat \\
2. & Rata-rata Nilai & 69,3 & 76,3 & 85,3 & Meningkat \\
3. & Ketuntasan Belajar & $51,6 \%$ & $83,9 \%$ & $100 \%$ & Meningkat \\
4 & Siswa Yg Belum Tuntas & $48,4 \%$ & $16,1 \%$ & $0 \%$ & \\
\hline
\end{tabular}

Hasil penelitian ini sejalan dengan hasil penelitian yang dilakukan oleh Kusumawati dan Randi (2016) yang berjudul Penerapan Metode Pembelajaran Drill Untuk Meningkatkan Kemampuan Pemecahan Masalah Matematis Siswa Kelas VIII SMP. Hasil penelitian menunjukkan bahwa terjadi peningkatan kualifikasi persentase rata-rata nilai akhir kemampuan pemecahan masalah matematis siswa dengan kualifikasi kurang pada siklus I menjadi kualifikasi baik sekali pada siklus II. Selain itu, juga terjadi peningkatan rata-rata nilai akhir untuk semua indikator kemampuan pemecahan masalah matematis siswa.

Begitu juga hasil dari penelitian yang dilakukan oleh Sutiah (2013) yang berjudul Peningkatan Hasil Belajarsiswa Melalui Metode Drill Materi Operasi Hitung Bilangan Bulat dan Pemecahan Masalah Pada Mata Pelajaran Matematika di Kelas V SDN 165726 Tebing Tinggi. Hasil penelitian menunjukkan bahwa penggunaan metode drill mata pelajaran matematika dapat meningkatkan hasil belajar siswa yang ditandai dengan peningkatan ketuntasan belajar siswa, yaitu siklus I (70,27\%), siklus II (89,18\%)dan dinyatakan berhasil secara klasikal $89,18 \%$.

\section{Simpulan Dan Saran}

Berdasarkan penelitian yang telah dilakukan, dapat disimpulkan bahwa: penerapan metoda latihan dalam pembelajaran mata pelajaran Bahasa Indonesia terbukti berhasil dalam meningkatkan hasil belajar siswa kelas XI.MM SMK Negeri 41 Jakarta dengan baik.

Berdasarkan kesimpulan yang telah dipaparkan pada bagaian sebelumnya maka pada bagian ini Peneliti menyampaikan beberapa saran sebagai berikut:

1. Bagi guru di SMK Negeri 41 Jakarta yang akan melakukan Penelitian Tindakan Kelas agar mencermati kelemahan-kelemahan siswa serta kondisi kelas yang akan diteliti, untuk lebih mempermudah pelaksanaan Penelitian yang akan dilakukan.

2. Penerapan metoda latihan dalam pembelajaran Bahasa Indonesia sangat tepat, untuk itu disarankan kepada guru Bahasa Indonesia hendaknya dapat menggunakan metoda latihan dalam Kegiatan Belajar mengajar Bahasa indonesia karena dapat mengaktifkan siswa dalam mengikuti pembelajaran Bahasa Indonesia.

3. Bagi siswa hendaknya selalu fokus dan berkosentrasi dengan baik dalam mengikuti Kegiatan Pembelajaran agar hasil yang dicapai siswa senantiasa meningkat

4. Bagi Sekolah: disarankan dapat memberikan dukungan bagi guru-guru yang akan melaksanakan Penelitian Tindakan Kelas untuk peningkatan mutu pembelajaran.

5. Bagi Peneliti: disarankan untuk mengembangkan penelitian ini sehingga kendala pada proses pembelajaran dapat diatasi dengan maksimal.

\section{Daftar Rujukan}

Efendi Yusuf, Mohammad, dkk. 2014. Penerapan Metode Pembelajaran Drill untuk Meningkatkan Hasil Belajar Peserta Didik pada Standar Kompetensi Mengukur dengan Menggunakan Alat Ukur. https://journal.unnes.ac.id/nju/index.php/. Diakses 14 Mei 2019.

Hamalik, Oemar. 2007. Kurikulum dan Pembelajaran. Jkaarta: Bina Aksara.

Idin, 2014. Peningkatan Hasil Belajar Siswa dalam Pembelajaran Bahasa Indonesia dengan Metode Drill di Kelas IV. http://jurnal.untan.ac.id/index.php/jpdpb/article/download/6455/pdf. Diakses 14 Mei 2019.

Kusumawati dan Randi. 2016. Penerapan Metode Pembelajaran Drill Untuk Meningkatkan Kemampuan Pemecahan Masalah Matematis Siswa Kelas VIII SMP. Jurnal Pendidikan Matematika, Volume 4, Nomor 1, April 2016, hlm 49 - 57. 
Nurlawati, Ayu, dkk. 2016. Penerapan Metode Pasangan Berbagi untuk Meningkatkan Keterampilan Menulis Surat Pribadi pada Pembelajaran Bahasa Indonesia. http://ejournal.upi.edu/index.php/ . Diakses 14 Mei 2019.

Puspita Tri Astuti, Dyta. 2016. Pengaruh Metode Drill and Practice Didukung Media Kertas Berpetak terhadap Kemampuan Menentukan Jaring-Jaring Berbagai Bangun Ruang Sederhana pada Siswa Kelas V SD Pawyatan Daha Kediri. http://simki.unpkediri.ac.id. Diakses 14 Mei 2019.

Rahmadani, Putri. 2015. Penggunaan Metode Latihan (Drill) untuk Meningkatkan Kemampuan Menulis Puisi Siswa Kelas III C. Http://Jurnal.Untan.Ac.Id/Index.Php/. Diakses 114 Mei 2019.

Sagala, Syaiful. 2007. Manajemen Strategik dalam Peningkatan Mutu. Pendidikan. Bandung: Alfabeta.

Sutiah. 2013. Peningkatan Hasil Belajarsiswa Melalui Metode Drill Materi Operasi Hitung Bilangan Bulat dan Pemecahan Masalah Pada Mata Pelajaran Matematika di Kelas V SDN 165726 Tebing Tinggi. Jurnal Unimed ESJ Volume 5, No. 1, Juni 2016.

Wahyuni, Nida. 2013. Penggunaan Metode Drill dalam Pembelajaran Matematika. https://journal.uncp.ac.id/index.php/proceding/article/view/576/505. Diakses 14 Mei 2019. 